\title{
Aplikasi Chatbot Objek Wisata Jawa Timur Berbasis AIML
}

\author{
Dhebys Suryani $^{1}$, Eka Larasati Amalia ${ }^{2}$
}

\begin{abstract}
Abstrak-- Pariwisata Jawa Timur memiliki potensi wisata yang banyak dikunjungi wisatawan. Namun pengembangan informasi pariwisata yang ada saat ini dirasa belum efektif dan efisien. Dalam penyampaian informasinya masih secara manual, seperti pemberian brosur, pamflet, dan poster bagi wisatawan yang mengunjungi obyek wisata. Karena itu, peneliti mencoba mengembangkan aplikasi chatbot berbasis AIML (Artificial Intelligence Markup Language). Dengan aplikasi ini nantinya wisatawan bisa mendapatkan informasi objek wisata dengan melakukan tanya jawab kepada sistem layaknya sebuah model diskusi. Aplikasi tersebut menggunakan bahasa sehari-hari atau bahasa alami (natural language) yang merupakan media yang digunakan manusia untuk berkomunikasi.
\end{abstract}

Kata Kunci-Wisata, Chatbot, AIML (Artificial Intelligence Markup Language).

\section{Pendahuluan}

Jawa awa Timur merupakan salah satu provinsi terbesar di Indonesia. Jawa Timur memiliki banyak lokasi wisata yang menarik untuk dikunjungi. Tak heran jika Jawa Timur menjadi destinasi wisatawan dari berbagai wiayah di Indonesia dan mancanegara. Namun tidak semua tempat-tempat menarik di Jawa Timur diketahui oleh wisatawan karena kurangnya informasi. Atas dasar masalah tersebut perlu dibuat sebuah aplikasi yang lebih menarik dan interaktif. Pengguna dapat melakukan interaksi tanya jawab dengan menggunakan bahasa sehari-hari layaknya model diskusi untuk mendapatkan informasi alamat tempat wisata.

Aplikasi chatbot adalah sebuah program komputer yang dirancang untuk menstimulasikan sebuah percakapan dengan satu atau lebih manusia. Tujuan penelitian ini adalah untuk menghasilkan sebuah aplikasi yang dapat melakukan percakapan dengan manusia, dan membantu manusia dengan menjawab pertanyaan yang diajukan oleh pengguna dengan menggunakan bahasa dan tata bahasa yang tepat. Metode penelitian yang dilakukan menggunakan AIML (Artificial Intelligence Markup Language), kemudian dengan menggabungkan beberapa teknik untuk membangun sebuah aplikasi yang mampu

\footnotetext{
Dhebys Suryani adalah pengajar di Program Studi Teknik Informatika Politeknik Negeri Malang; email dhebys.suryani@gmail.com

${ }^{2}$ Eka Larasati Amalia adalah pengajar di Program Studi Teknik Informatika Politeknik Negeri Malang; email : ekalarasati.a@gmail.com
}

melakukan percakapan dengan manusia. Hasil dari penelitian ini adalah aplikasi yang mampu melakukan percakapan dengan manusia dengan menggunakan bahasa alami, menjawab pertanyaan yang diberikan oleh pengguna, dan mencari jawaban dengan menggunakan teknologi internet.

\section{TINJAUAN PUSTAKA}

\section{Chatbot}

Chatbot adalah program komputer yang dapat melakukan percakapan melalui media tulisan. Percakapan dapat terjadi dengan manusia atau chatbot yang lain. Secara harfiah chatbot berasal dari dua kata yaitu chat bot. Dalam dunia komputer chat dapat diartikan sebagai kegiatan komunikasi yang menggunakan sarana tulisan. Sedangkan bot merupakan program yang memiliki sejumlah data yang bila diberi input akan menghasilkan output sebagai jawaban.

Chatbot adalah salah satu sistem cerdas yang dihasilkan dari Pemrosesan Bahasa Alami atau Natural Language Processing (NLP) yang merupakan salah satu cabang dari Kecerdasan Buatan atau Artificial Intelligence (AI).

\section{Artificial Intellegence Markup Language (AIML)}

Artificial Intelligence Markup Language (AIML) adalah sebuah bahasa yang mendeskripsikan objek data dan perilaku program komputer yang memprosesnya. AIML sendiri merupakan turunan dari Extensible Markup Language (XML).

Obyek AIML tersusun atas unit-unit yang disebut topics dari categories, berisi data yang sudah ter-parsing maupun belum ter-parsing. Data yang ter-parsing berisi karakter-karakter, beberapa di antaranya berupa data karakter, yang lainnya dapat berupa elemen AIML. Elemen AIML mengkaspulasi pengetahuan dalam bentuk stimulus-response di dokumen.

AIML berisi kumpulan pola dan respon yang dapat digunakan oleh chatbot untuk penelusuran jawaban setiap kalimat yang diberikan. Interpreter AIML diperlukan untuk menerima input dan melakukan penelusuran jawaban pada dokumen AIML. Saat ini tersedia hanyak interpreter AIML dalam berbagai bahasa pemrograman sehingga proses pembuatan chatbot dapat terfokus pada penyusunan dokumen AIML. Selain itu juga saat ini di internet banyak tersedia dokumen AIML siap pakai untuk berbagai bidang percakapan. Bagian-bagian penting dari AIML adalah sebagai berikut

1. Category 
Pada AIML, category merupakan unit dasar dari pengetahuan. Category minimal terdiri dari dua element AIML yaitu pattern dan template.Berikut adalah contoh category yang sederhana:

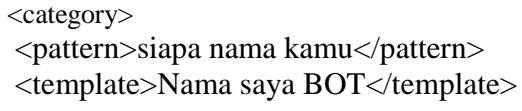

Ketika category di atas dimuat di memory maka bot AIML akan menjawab pertanyaan "Siapa nama kamu" dengan "Nama saya BOT".

2. Pattern

Pattern adalah sebuah rangkaian huruf yang diharapkan sesuai/cocok dengan satu atau bahkan lebih dengan masukan (input) pengguna. Suatu pattern dapat menggunakan wildcard yang akan cocok dengan satu atau lebih masukan pengguna.

Tabel1. Pattern AIML

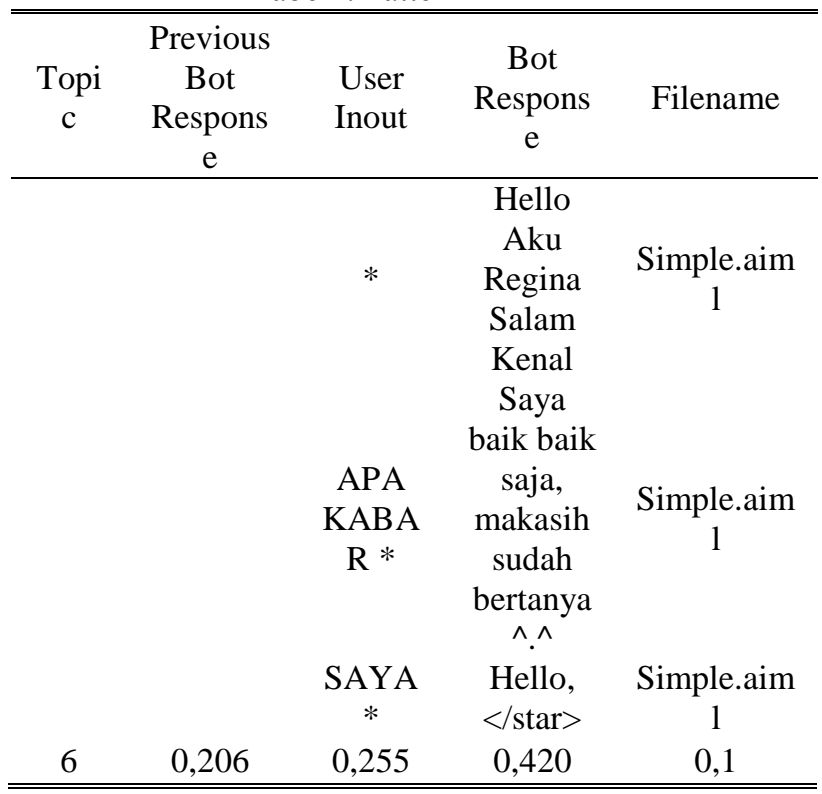

Keterangan Tabel

$\mathrm{x}_{1}$ : Data input umur

$\mathrm{x}_{2}$ : Data input berat badan

\section{Template}

Suatu template menentukan respon dari pattern yang sesuai.

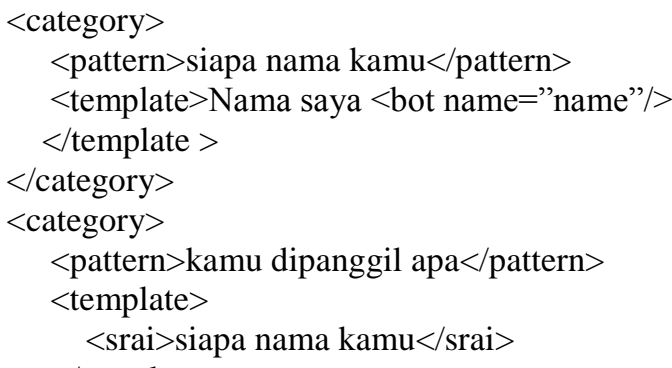

Category pertama akan menjawab sebuah masukan "siapa nama kamu" dengan sebuah pernyataan mengenai nama bot. Category kedua akan menjawab masukan "kamu dipanggil apa" dengan meneruskan pertanyaan tersebut ke category pertama yang cocok dengan masukan "siapa nama kamu"-dengan kata lain bahwa dua frase tersebut sebanding atau sama.

4. That

That merupakan element AIML yang mengacu pada respon atau keluaran sebelumnya. That sering digunakan pada pembuatan category agar respon yang dihasilkan masih berkaitan dengan pertanyaan atau jawaban sebelumnya

Dalam perancangan template, dilakukan pembuatan daftar <pattern> sebagai perkiraan masukan dari user. Pattern tersebut terdiri dari berbagai bentuk untuk suatu respon <template>. Template juga terdiri dari berbagai bentuk sebagai jawaban masukan dari user agar tidak terlihat kaku dengan merespon jawaban yang sama.

\section{Program $O$}

Program-O (www.program-o.com), sebuah interpreter chatbot berbasis AIML yang ditulis menggunakan bahasa PHP. Interpreter ini dilengkapi dengan panel kontrol untuk botmaster dalam mengelola pengetahuan chatbot yang meliputi penambahan pengetahuan dari file AIML ekstemal, pengeditan pengetahuan, dan lain-lain. Aplikasi ini belum mendukung interaksi dengan modul pemroses pengetahuan tambahan.

\section{Metode Penelitian}

\section{Analisa Kebutuhan Sistem}

Analisis kebutuhan sistem ini digunakan untuk menerapkan sistem baru. Sistem yang baru harus bisa difungsikan dengan baik sesuai dengan kebutuhan.

1. Kebutuhan Perangkat Keras

Perangkat keras (hardware) yang dibutuhkan adalah Personal Computer (PC) atau notebook yang terhubung dengan jaringan internet dengan spesifikasi minimal sebagai berikut :

Personal Computer (PC) :

- Processor Core 2 Duo RAM 2 GB

- Monitor

- Mouse

- Keyboard

2. Kebutuhan Perangkat Lunak

Untuk membangun sistem ini diperlukan perangkat lunak (software) sebagai berikut :

- Sublime Text 3 sebagai tools untuk menulis kode program web.

- PHPMyAdmin sebagai penyimpanan database.

- Browser untuk menjalankan aplikasi berbasis web. Misalkan: Mozila Firefox, Google Chrome.

- Windows 7 Ultimate sebagai sistem operasi yang digunakan untuk mengakses aplikasi.

\section{Analisa Pengguna Sistem}

Pada aplikasi ini terdapat dua interface user dan admin. Pada interface admin yang berbasis website terdapat rancangan form login yang ditujukan kepada admin untuk memasukan username dan password untuk dapat masuk ke halaman admin, hal ini digunakan untuk 
menghindari penyalahgunaan yang dilakukan oleh pihak yang tidak bertanggung jawab. Admin bertugas untuk mengelola data wisata.

Pada halaman user interface berbasis website, ditampilkan berupa kolom pertanyaan untuk user memasukkan pertanyaan tentang objek wisata dan kolom jawaban untuk respon jawaban dari sistem.

\section{Perancangan Sistem}

Sistem ini menggunakan struktur WBS (Work Breakdown Structure) untuk pengorganisasian sistemnya. WBS yang digunakan terdiri dari data dan layanan. Data berisi tentang data wisata, data informasi wisata, data lokasi wisata, data tempat masuk wisata, data rute wisata, dan data fasilitas wisata. Untuk layanan sistem ini memiliki beberapa layanan yaitu respon jawaban sistem, informasi wisata, lokasi wisata, tiket masuk wisata, rute dan fasilitas wisata. Agar sistem dapat terorganisir menjadi struktur yang lebih detail dalam tiap prosesnya maka di buat work breakdown structure seperti pada Gambar 1.

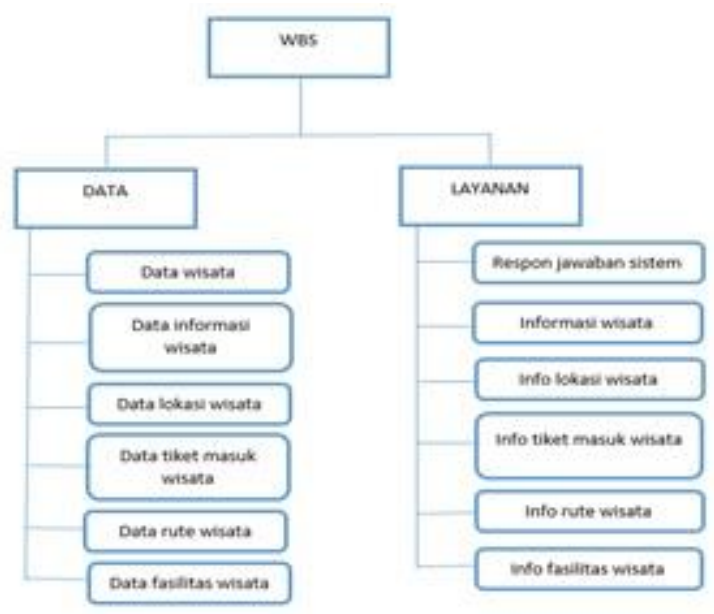

Gambar 1 Desain Work Breakdown Structure

Keterangan :

a. Data :

- Data wisata merupakan data-data objek-objek wisata yang berada di Jawa Timur.

- Data informasi wisata merupakan data-data yang berisikan informasi wisata di Jawa Timur seperti asal usul atau cerita singkat dari tempat wisata.

- Data lokasi wisata merupakan data-data lokasi atau alamat-alamat tempat wisata yang berada di Jawa Timur.

- Data tiket masuk wisata merupakan kumpulan data-data harga tiket masuk wisata di Jawa Timur.

- Data rute wisata merupakan data-data rute menuju tempat wisata di Jawa Timur.

- Data fasilitas wisata merupakan data-data fasilitas yang terdapat pada tempat wisata yang berada di Jawa Timur.

b. Layanan :

- Respon jawaban sistem yang diberikan apabila user memasukkan pertanyaan.

- Informasi wisata merupakan layanan yang diberikan oleh sistem untuk user apabila user memasukkan pertanyaan mengenai apasaja objek wisata di Jawa Timur.

- Info lokasi wisata merupakan layanan yang diberikan oleh sistem untuk user apabila user memasukkan pertanyaan mengenai lokasi tempat wisata yang ada di Jawa Timur.

- Info tiket masuk wisata merupakan layanan yang di berikan sistem untuk user apabila user memasukkan pertanyaan harga tiket masuk tempat wisata di Jawa Timur.

- Info rute wisata merupakan layanan yang di berikan sistem untuk user apabila user memasukkan pertanyaan rute tempat wisata di Jawa Timur.

- Info fasilitas wisata merupakan layanan yang diberikan sistem untuk user apabila user memasukkan pertanyaan fasilitas tempat wisata di Jawa Timur.

Pada perancangan fungsi Aplikasi Chatbot Objek Wisata Jawa Timur Berbasis AIML dapat dilihat pada Data Flow Diagram (DFD) berikut :

\section{DFD Level 0}

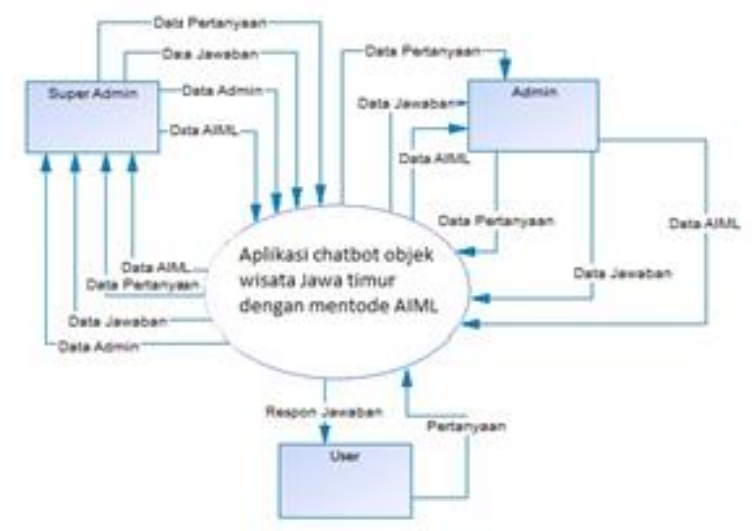

Gambar 2. DFD Level 0

\section{DFD Level 1}

DFD Level 1 untuk Rancang Bangun Aplikasi Chatbot Objek Wisata Jawa Timur Berbasis AIML. Pada level ini dapat dijabarkan secara lebih detail tentang sistem ditunjukan pada Gambar 3.1

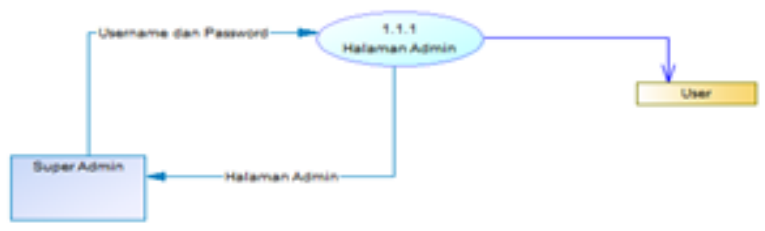

Gambar 3 DFD Level 1

\section{DFD Level 2 proses mengelola Halaman Super Admin}

Pada DFD Level 2 halaman super admin, terdapat sub proses halaman admin. Super admin password. Setelah itu data tersebut akan di verifikasi, jika benar admin dapat masuk ke halaman admin.akan memasukkan username dan password 


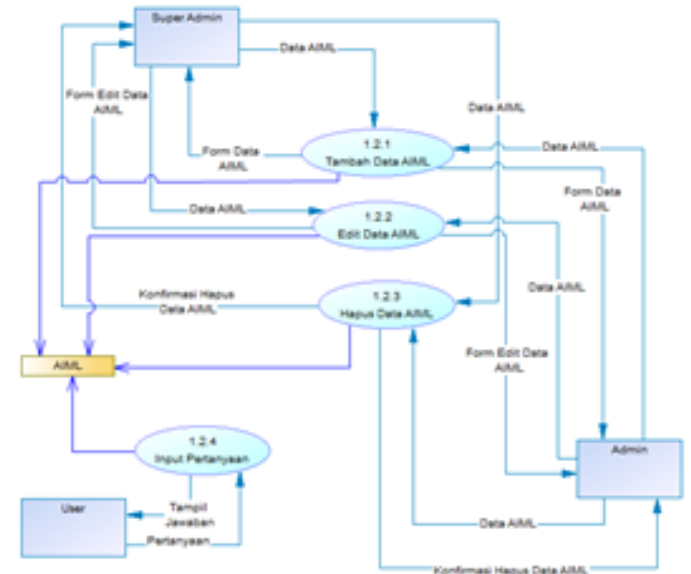

Gambar 4 Desain DFD Level 2 Login Super Admin

\section{DFD Level 2 Proses Mengelola Super Admin, Admin, User}

Super admin mengisi form untuk menambah data AIML. Data yang telah diisikan dan berhasil disimpan pada database akan masuk kedalam tabel AIML. Super admin juga dapat mengubah dan menghapus data aiml.

Admin juga dapat mengisi form untuk menambah data AIML. Kemudian data yang diisikan dan berhasil akan disimpan pada database dan masuk kedalam tabel AIML.

User memasukkan pertanyaan kemudian pertanyaan yang dimasukkan akan dicari di database. Setelah pertanyaan yang dimasukkan sesuai dengan data yang ada di database maka akan tampil jawaban untuk user.

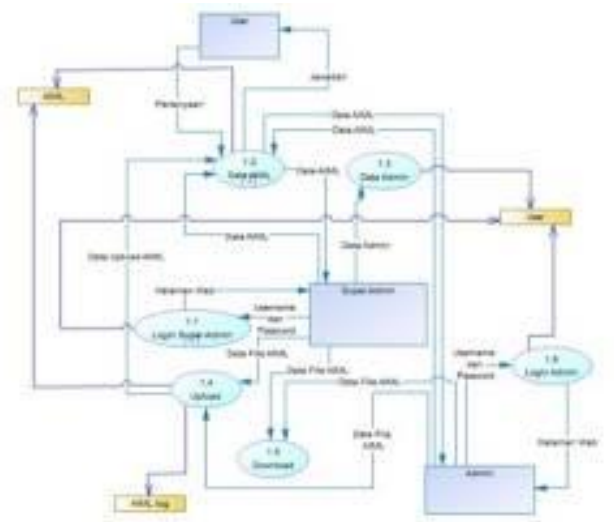

Gambar 5 Desain DFD Level 2 Login Super Admin, Admin, User

\section{Flowchart}

Flowchart adalah suatu bagan dengan simbol-simbol tertentu yang menggambarkan urutan proses secara mendetail dan hubungan antara suatu proses (instruksi) dengan proses lainnya dalam suatu program.

Pada perancangan sistem Rancang Bangun Aplikasi Chatbot Objek Wisata Jawa Timur Berbasis AIML dapat dilihat pada flowchart yang ditunjukkan pada Gambar 6.

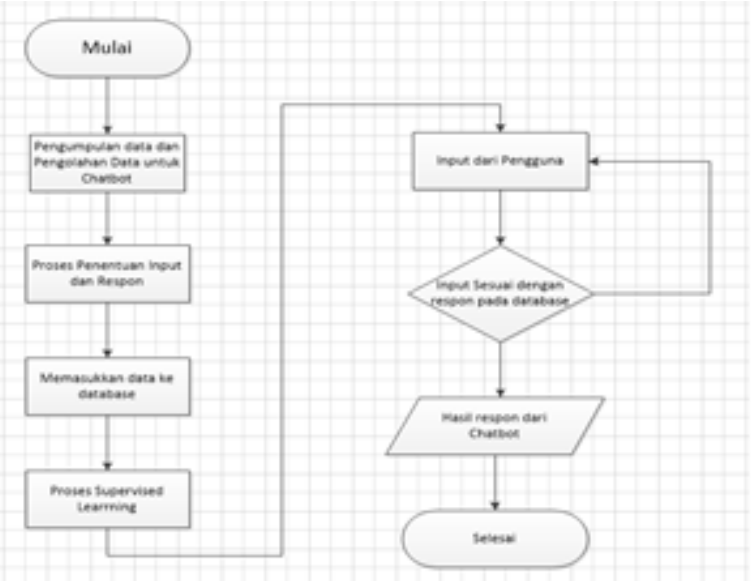

Gambar 6. Flowchart

\section{Implementasi}

Implementasi basis data dari sistem aplikasi ini dirancang menggunakan database MySQL. terdapat 9 tabel pada database, yaitu tabel aiml, tabel aiml_userdefined, tabel aiml_log, tabel bots, tabel botspersonality, tabel conversation_log, tabel user, tabel client_properties, tabel srai_lockup dan tabel users. Berikut ini merupakan rincian dari masingmasing tabel :

a. Tabel aiml

Tabel ini berfungsi untuk menyimpan data pertanyaan dan jawaban. Tabel aiml ditunjukkan pada Gambar 7.

\begin{tabular}{lll}
\hline Name Type Collation & Attributes Null Default Extra \\
\hline 1 id int(11) & No None AUTO_INCREMENT \\
2 bot tinyint(4) & No 0 \\
3 name varchar(255) latin1_swedish_ci & No \\
\hline value text $\quad$ latin1_swodish_ci & No None \\
\hline
\end{tabular}

Gambar 7 Tabel AIML

b. Tabel aiml_log

Tabel ini berfungsi untuk mengetahui perubahan file aiml yang terdapat pada server. Tabel aiml_log ditunjukkan pada Gambar 8

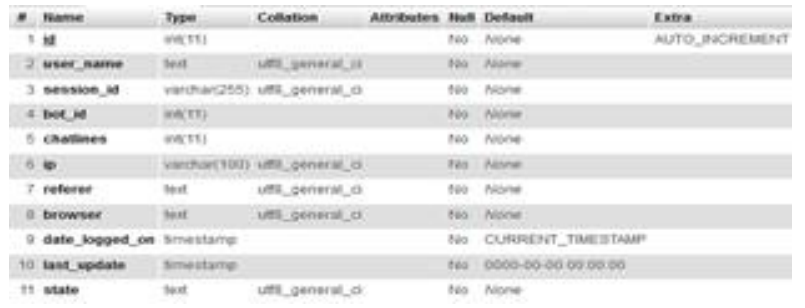

Gambar 8. Tabel aiml_log

c. Tabel aiml_userdefined

Tabel ini berfungsi untuk menggambarkan jawaban yang akan diberikan untuk user. Tabel aiml_userdefined ditunjukkan pada Gambar 9.

\begin{tabular}{|c|c|c|c|c|c|c|c|}
\hline & ; Nume & Tppe & Collation & Amibutes & Nall & Defout & Extro \\
\hline 0 & 1 is & $\mathrm{m}(10)$ & & & No & None & \\
\hline 0 & 2 usemase & varchar(255) & Ite1_sutdsh_o & & No & None & \\
\hline 0 & 3 flesume & wacher(285) & Iater_sutdsh_o & & No & None & \\
\hline 0 & 4 tinestamp & imestamp & & o wim combor, fwethos & No & CURRENT_TMESTAUP & ON UPOATE \\
\hline
\end{tabular}

Gambar 9 Tabel aiml_userdefined 
d. Tabel bots

Tabel ini berfungsi untuk menyimpan nama dari chatbot. Tabel bots ditunjukkan pada Gambar 10.

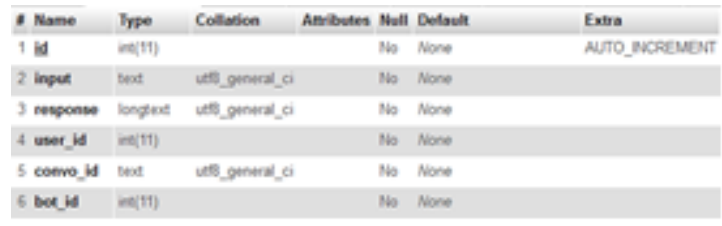

Gambar 10 Tabel bots

e. Tabel botspersonality

Tabel ini berfungsi untuk menyimpan data diri dari chatbot. Tabel botspersonality ditunjukkan pada Gambar 11.

\begin{tabular}{|l|lll|}
\hline "Name & Type Collation Attributes Null Default Extra \\
\hline 1 id & int(11) & No None AUTO_INCREMENT \\
\hline 2 bot_id & int(11) & No None \\
\hline 3 pattern & text utfo_general_ci & No None \\
\hline 4 template_id int(11) & No None \\
\hline
\end{tabular}

\section{f. Tabel conversation_log}

\section{Gambar 11 Tabel botspersonality}

Tabel ini berfungsi untuk menyimpan rekaman percakapan. Tabel conversation_log ditunjukkan pada Gambar 12.

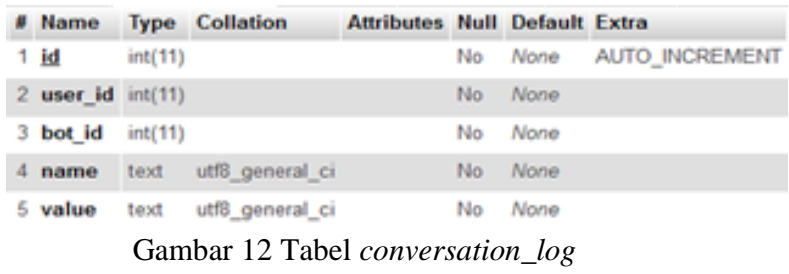

g. Tabel client_properties

Tabel ini berfungsi untuk mengidentifikasi user. Tabel client_properties ditunjukkan pada Gambar 13.

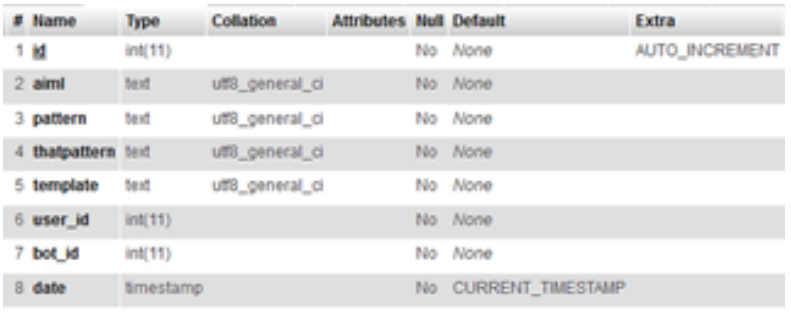

Gambar 13 Tabel client_properties

h. Tabel srai_lookup

Tabel ini berfungsi untuk mengidentifikasi pertanyaan dan jawaban. Tabel srai_lookup ditunjukkan pada Gambar 14.

i. Tabel user

Tabel ini berfungsi untuk menyimpan data admin. Tabel user ditunjukkan pada Gambar 15.

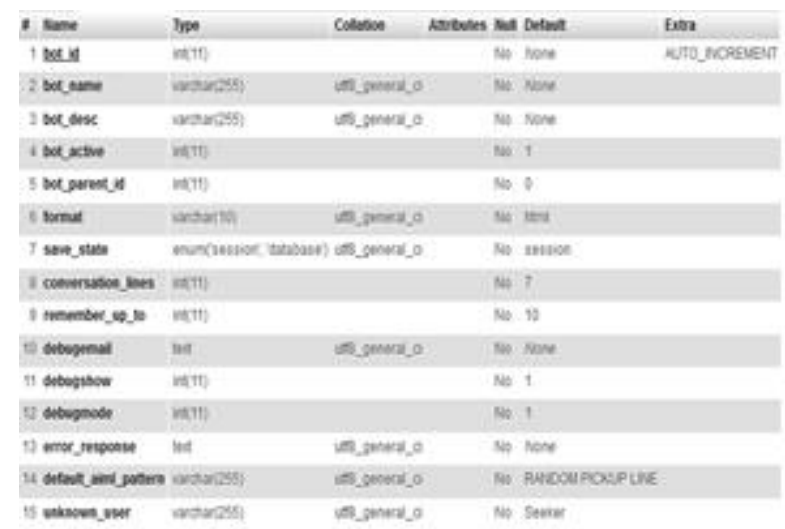

Gambar 14 Tabel srai_lookup

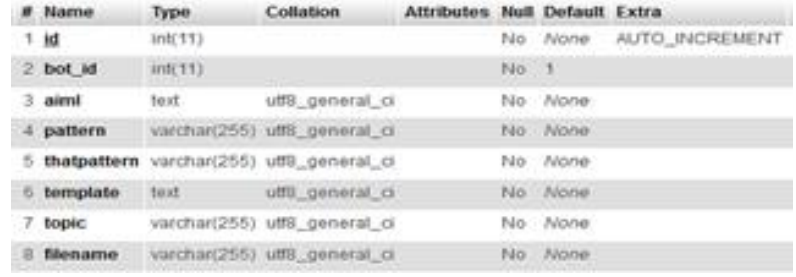

Gambar 15 Tabel user

\section{HASIL DAN PEMBAHASAN}

\section{Pengujian}

Pengujian dilakukan untuk mencari seberapa akurat jawaban yang mampu diberikan oleh sistem. Dengan memberikan beberapa pola pertanyaan yang jawabannya merujuk satu jawaban seperti pada tabel 2 .

Tabel 2. Uji Coba Sistem

\begin{tabular}{|l|l|l|c|}
\hline No & Pertanyaan & \multicolumn{1}{|c|}{ Jawaban Sistem } & Cocok \\
\hline 1. & $\begin{array}{l}\text { Dimana } \\
\text { posisi lokasi } \\
\text { coban } \\
\text { pelangi }\end{array}$ & $\begin{array}{l}\text { Lokasi Coban Pelangi } \\
\text { berada di desa } \\
\text { Poncokusumo dengan } \\
\text { jarak sekitar 32 km } \\
\text { dari kota Malang. }\end{array}$ & $\sqrt{ }$ \\
\hline 2. & $\begin{array}{l}\text { Lokasi } \\
\text { coban } \\
\text { pelangi }\end{array}$ & $\begin{array}{l}\text { Lokasi Coban Pelangi } \\
\text { berada di desa } \\
\text { Poncokusumo dengan } \\
\text { jarak sekitar 32 km } \\
\text { dari kota Malang. }\end{array}$ & $\sqrt{ }$ \\
\hline 3. & $\begin{array}{l}\text { Dimana } \\
\text { lokasi } \\
\text { Coban } \\
\text { Pelangi }\end{array}$ & $\begin{array}{l}\text { Lokasi Coban Pelangi } \\
\text { berada di desa } \\
\text { Poncokusumo dengan } \\
\text { jarak sekitar 32 km } \\
\text { dari kota Malang. }\end{array}$ & $\sqrt{ }$ \\
\hline 4. & $\begin{array}{l}\text { Letak lokasi } \\
\text { coban } \\
\text { pelangi }\end{array}$ & $\begin{array}{l}\text { Lokasi Coban Pelangi } \\
\text { berada di desa } \\
\text { Poncokusumo dengan } \\
\text { jarak sekitar 32 km } \\
\text { dari kota Malang. }\end{array}$ & $\sqrt{ }$ \\
\hline 5. & $\begin{array}{l}\text { Air terjun } \\
\text { dimalang }\end{array}$ & $\begin{array}{l}\text { maaf saya tidak } \\
\text { mengetahuinya, } \\
\text { mungkin yang anda } \\
\text { masukkan salah atau } \\
\text { kurang lengkap? }\end{array}$ & $\mathrm{x}$ \\
\hline
\end{tabular}


Hasil implementasi

1. Halaman awal user SICHAPAR

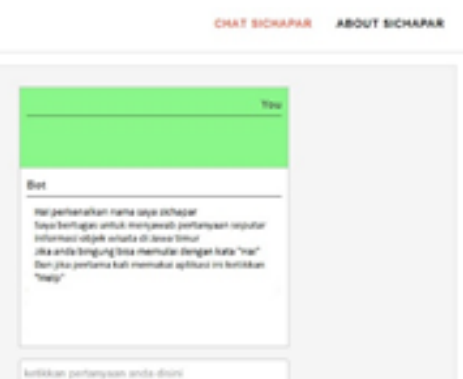

Gambar 16 screenshot halaman awal chat SICHAPAR

Pada halaman ini merupakan tampilan CHAT SICHAPAR yaitu kolom chabot yang berfungsi untuk menanyakan pertanyaan tentang informasi objek wisata yang berada di provinsi jawa timur. Halaman CHAT SICHAPAR ditunjukkan gambar 16

2. Halaman chat dengan sichapar

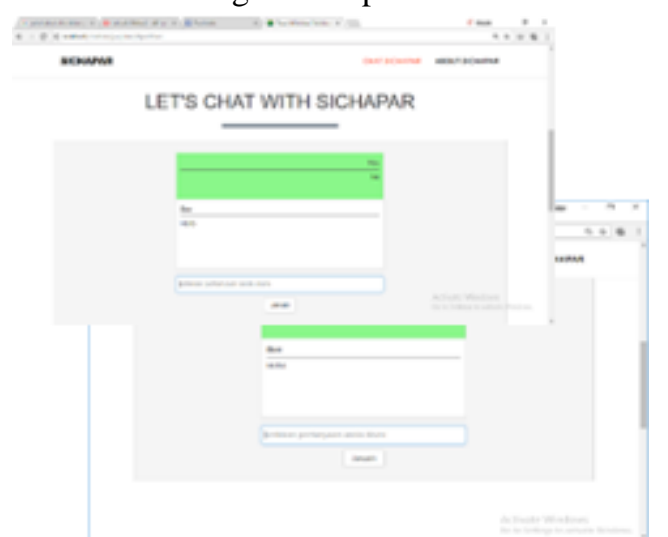

Gambar 17 screenshot tampilan halaman chat dengan sichapar

Halaman ini menampilkan tampilan chat dengan sichapar, jika user ingin memulai chat dengan sichapar ini, cukup mengetikkan kata hai

3. Halaman tampilan admin

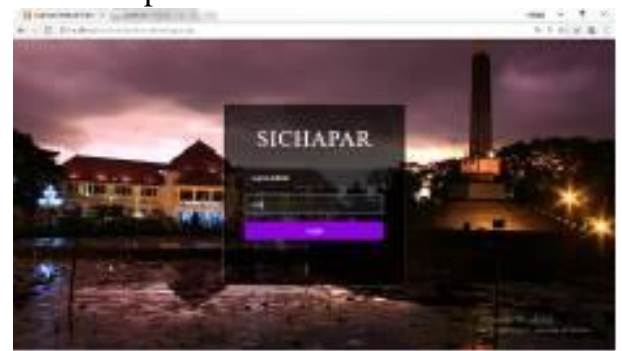

Gambar 18 Screenshot tampilan login admin

Login Admin merupakan syarat untuk dapat menggunakan program secara keseluruhan. Pada halaman login, admin mengoperasikan sistem dengan login pada halaman ini dengan memasukkan username dan password, maka akan keluar ke halaman home admin. Pada halaman login ini, apabila admin salah memasukkan username dan password maka akan muncul peringatan dan harus mengulanginya kembali hingga dapat masuk ke dalam sistem. Tampilan halaman login ditunjukkan pada Gambar

4. Halaman home super admin

Halaman ini merupakan tampilan utama dari super admin. Halaman ini akan tampil setelah super admin berhasil login dengan memasukkan username dan password yang benar. Halaman home super admin ditunjukkan pada Gambar 19.

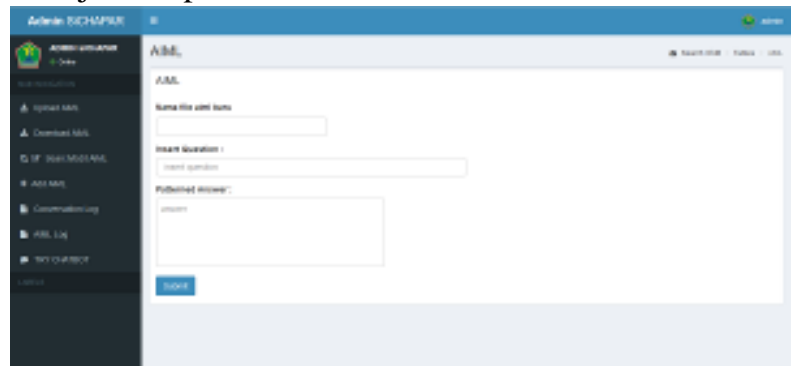

Gambar 19 screenshot home super admin

5. Halaman home admin

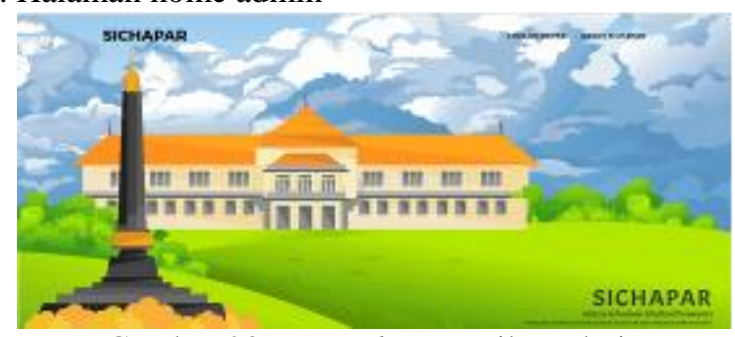

Gambar 20 screenshot tampilan admin

Halaman ini merupakan tampilan utama dari admin. Halaman ini akan muncul setelah admin berhasil login dengan memasukkan username dan password yang benar.

\section{Halaman admin}

Halaman admin memiliki menu-menu yang sama dengan super admin hanya saja pada halaman admin, admin tidak bisa menambahkan data admin. Halaman Home Admin ditunjukkan pada Gambar 21.

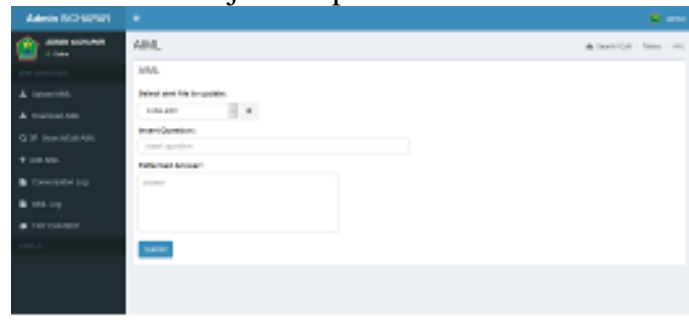

Gambar 21 screenshot tampilan halaman admin

7. Halaman upload AIML

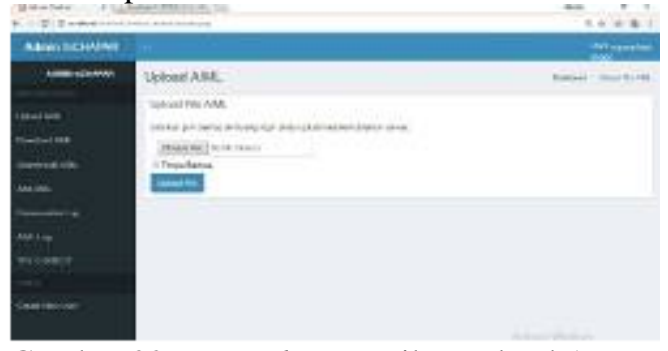

Gambar 22 screenshot tampilan upload AIML

Halaman ini merupakan tampilan Upload AIML yang berfungsi untuk mengunggah file aiml. Halaman Home Upload AIML ditunjukkan pada Gambar 22

8. Halaman download AIML

Pada halaman ini merupakan tampilan Download AIML yang berfungsi untuk mengunduh file aiml yang telah di unggah. Halaman Download AIML ditunjukkan pada Gambar 23

9. Halaman search/edit AIML 
Pada halaman ini merupakan tampilan Search/edit AIML berfungsi untuk menampilkan data pertanyaan dan data jawaban yang dapat melakukan pencarian data, mengubah data dan menghapus data. Halaman Search/edit AIML ditunjukkan pada Gambar 24.

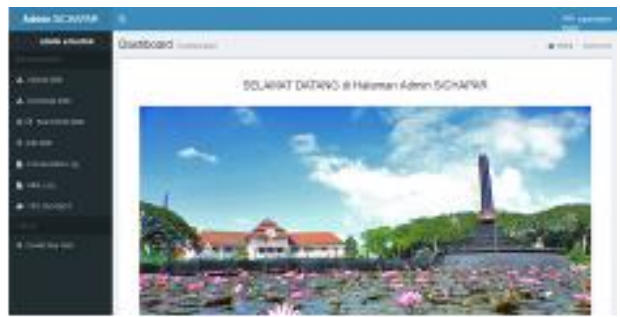

Gambar 23 screenshot tampilan halaman download AIML

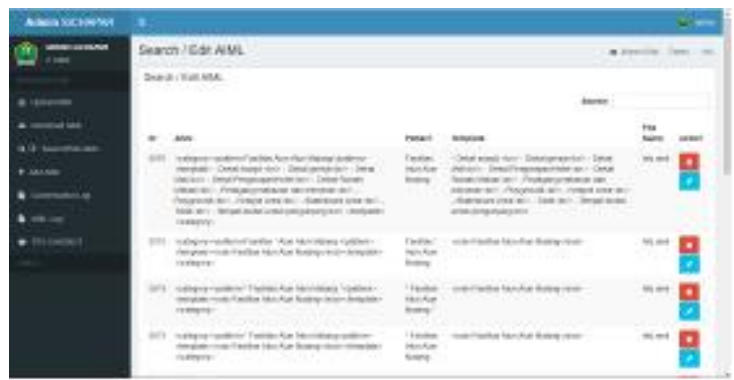

Gambar 24 screenshot tampilan halaman search/edit AIML

10. Halaman Add AIML

Pada halaman ini merupakan tampilan Add AIML yang berfungsi untuk menambah data pertanyaan dan data jawaban. Button + berfungsi untuk menambah file aiml. Halaman Add AIML ditunjukkan pada Gambar 25.

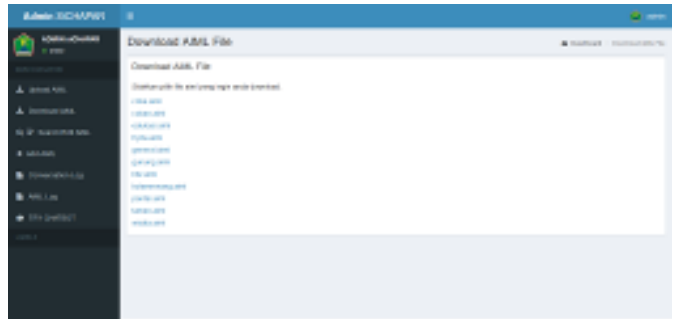

Gambar 25 screenshoot tampilan halaman Add AIML 11. Halaman AIML log

Pada menu AIML_log merupakan halaman yang berfungsi untuk mengetahui perubahan file aiml yang terdapat pada server. Halaman AIML_log ditunjukkan pada Gambar 26.

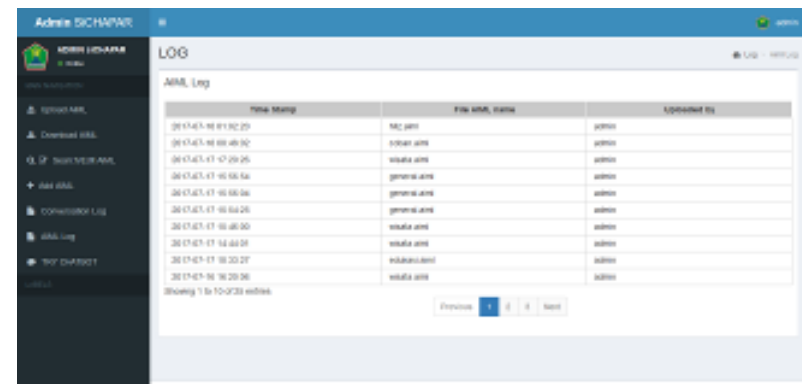

Gambar 26 screenshot tampilan halaman AIML log

12. Halaman conversation $\log$

Pada menu Conversation_log merupakan halaman untuk merekam percakapan pada chatbot. Halaman Conversation_log ditunjukkan pada Gambar 27.

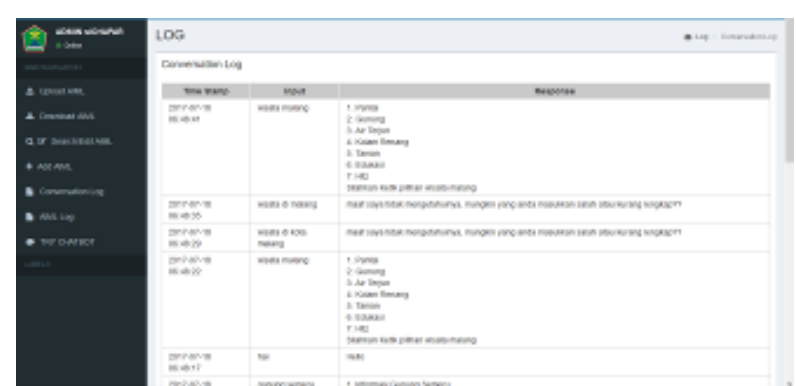

Gambar 27 screenshoot tampilan halaman conversation $\log$

\section{KESIMPULAN DAN SARAN}

\section{Kesimpulan}

Berdasarkan pembahasan yang diperoleh, maka dapat ditarik kesimpulan sebagai berikut :

a. Sistem informasi rancang bangun aplikasi chatbot objek wisata Jawa Timur berbasis AIML dapat memberikan informasi kepada wisatawan yang ingin berwisata di kota Jawa Timur..

b. Sistem informasi rancang bangun aplikasi chatbot objek wisata Jawa Timur berbasis AIML dapat membantu wisatawan untuk mengetahui informasi wisata, lokasi wisata, harga tiket wisata, rute wisata, fasilitas wisata.

\section{Saran}

Untuk pengembangan sistem informasi rancang bangun aplikasi chatbot objek wisata Jawa Timur berbasis AIML lebih lanjut agar semakin memberikan manfaat untuk user ada beberapa hal yang bisa dijadikan bahan kajian lebih lanjut, yaitu

a. Untuk kedepannya disarankan chatbot dapat menambahkan respon inputan dengan kata-kata yang salah dalam pengetikan.

b. Untuk kedepannya disarankan chatbot menambahkan informasi-informasi wisata menjadi lebih luas.

c. Untuk kedepannya disarankan chatbot dapat belajar sendiri.

\section{DAFTAR PUSTAKA}

[1] H. Nawawi, Organisasi Sekolah dan Pengelolaan Kelas Sebagai Lembaga Pendidikan. Jakarta: Gunung Agung, 1982.

[2] R. Munir, Matematika Diskrit. Bandung: Informatika, 2005.

[3] S. Kusumadewi, Analisis dan Desain Sistem Fuzzy Menggunakan Tool Box Matlab. Yogyakarta: Graha Ilmu, 2003.

[4] J. C. Dunn, "A Fuzzy Relative of the ISODATA Process and Its Use in Detecting Compact, Well Separated Clusters," J. Cybern., vol. 3, no. 3, pp. 32-57, 1973.

[5] J. C. Bezdek, Pattern Recognition with Fuzzy Objective Function Algoritms. New York: Plenum Press, 1981.

[6] P. Valarmathie, M. Srinath, T. Ravichandran, and K. Dinakaran, "Hybrid Fuzzy C-Means Clustering Technique for Gene Expression Data," Int. J. Res. Rev. Appl. Sci., vol. 1, no. 1, pp. 33-37, 2009. 
[7] Polinema, Pedoman Akademik Tahun 2016. Malang: Politeknik Negeri Malang, Jurusan Teknologi Informasi, 2016.

[8] B. S. Duran and P. L. Odell, Cluster Analysis : A Survey. New York: Springer-Verlag, 1974.

[9] Y. Agusta, "K-Means-Penerapan, Permasalahan dan Metode Terkait," J. Sist. dan Inform., vol. 3, no. 1, pp. 47-60, 2007.

[10] R. Sharma, M. A. Alam, and A. Rani, "KMeans Clustering in Spatial Data Mining using Weka Interface," in IJCA Proceedings on International Conference on Advances in Communication and Computing Technologies 2012, 2012, pp. 26-30. 